\title{
Kondisi Penyimpanan Kacang Tanah dan Potensi Cemaran Aspergillus flavus pada Pedagang Pengecer Pasar Tradisional di Wilayah Jakarta
}

\author{
Peanut Storage Condition and Aspergillus flavus Contamination Potential at Traditional Market Retailers in \\ Jakarta Area
}

\section{Widya Eka Prayitno, Harsi Dewantari Kusumaningrum*, Hanifah Nuryani Lioe}

\author{
Departemen Ilmu dan Teknologi Pangan, Fakultas Teknologi Pertanian, Institut Pertanian Bogor, Jl. Raya Darmaga, \\ Kampus IPB Darmaga, Bogor 16680, Indonesia \\ *Email: harsikusumaningrum@yahoo.com
}

Submisi: 19 Juni 2017; Penerimaan: 17 Januari 2018

\begin{abstract}
ABSTRAK
Faktor-faktor yang mempengaruhi cemaran aflatoksin pada biji kacang tanah atau ose di wilayah Jakarta belum pernah dilaporkan. Penelitian ini dilakukan di pasar tradisional dengan 15 pedagang pengecer kacang tanah sebagai responden $(n=15)$. Tujuan penelitian adalah mengidentifikasi dan mengevaluasi kondisi penyimpanan dan perilaku pengecer dalam menyimpan kacang tanah serta mengidentifikasi potensi cemaran Aspergillus flavus pada kacang tanah. Tahap penelitian meliputi survei di area pengecer (wawancara, pengamatan langsung dan pengukuran suhu serta kelembaban relatif (RH) di area penyimpanan) serta analisis kacang tanah (kadar air, biji cacat, dan keberadaan $A$. flavus). Hasil studi menunjukkan rata-rata kisaran suhu area penyimpanan kacang tanah di kios pengecer berkisar antara $29,6-31,2^{\circ} \mathrm{C}$. Hal ini tidak sesuai dengan rekomendasi Codex Alimentarius Commission (CAC), meskipun sebagian besar rata-rata kisaran RH area penyimpanan berkisar antara 53,6-73,1\% dan kadar air kacang tanah sebesar 6,23-7,86\% yang sesuai dengan rekomendasi CAC. Rata-rata biji rusak, biji keriput dan biji belah ditemukan pada kisaran, berturut-turut, 3,9-19,1\%, 5,4-32,3\% dan 0,2-8,8\%. Rata-rata total kapang dan $A$. flavus pada sampel kacang tanah, masing-masing, ditemukan berkisar antara 2,5-5,6 log cfu/g dan 1,3-4,0 log $\mathrm{cfu} / \mathrm{g}$. Total kapang pada sampel kacang tanah memiliki korelasi positif yang kuat dengan biji rusak $(r=0,74)$, dan berkorelasi positif pada tingkat sedang dengan suhu $(r=0,41)$, kadar air $(r=0,42)$ dan perilaku pengecer dalam pembersihan langit-langit kios $(r=0,44)$ serta penempatan wadah simpan kacang tanah $(r=0,44)$. Studi ini menunjukkan bahwa keberadaan $A$. flavus pada sampel kacang tanah berkorelasi positif lemah dengan kelembaban relatif di area penyimpanan $(r=0,26)$ dan tidak memiliki korelasi secara signifikan dengan biji rusak maupun semua kondisi penyimpanan lainnya.
\end{abstract}

Kata kunci: Cemaran aflatoksin; Aspergillus flavus, kacang tanah; pedagang pengecer; pasar tradisional

\section{ABSTRACT}

Factors affecting contamination on peanut kernel marketed in Jakarta has not been investigated yet. The purpose of the research was to investigate and evaluate the storage condition and the behavior of retailers on the way of peanuts storage and also to investigate the presence of Aspergillus flavus infection in the peanuts. The research was conducted at traditional market with 15 peanut retailers as respondents $(n=15)$. The research stages included survey at retailer area including interview, observation, temperature and relative humidity measurements as well as peanuts analysis including moisture content, defective seeds and presence of $A$. flavus. The results of research revealed that the average temperature of peanut storage area at retail stalls range from 29.6 to $31.2^{\circ} \mathrm{C}$ which is not in accordance with the Codex Alimentarius Commission (CAC) recommendation, while the average of storage room RH ranged between $53.6-73.1 \%$ and moisture content of peanuts of $6.23-7.86 \%$ were mostly in accordance to CAC recommendation. The percentage of damage, shrivelled and splitted seeds ranged between 3.9-19.1\%, 5.4-32.3\% and $0.2-8.8 \%$, respectively. The range of mean of total molds and $A$. flavus were $2.5-5.6 \mathrm{log} \mathrm{cfu} / \mathrm{g}$ and $1.3-4.0 \mathrm{log}$ $\mathrm{cfu} / \mathrm{g}$, respectively. Total molds had a strong correlation to damage kernels $(r=0.74)$, and had a moderate correlation to the temperature $(r=0.41)$, moisture content $(r=0.42)$ and behavior of retailers, especially in cleaning the ceiling $(r=0.44)$ and placing the storage container $(r=0.44)$. The presence of $A$. flavus had a slight

DOI: http://doi.org/10.22146/agritech.26113

ISSN 0216-0455 (Print), ISSN 2527-3825 (Online) 
correlation to relative humidity on storage $(r=0.26)$, and had no significant correlation to peanuts damage and all storage conditions.

Keywords: Aflatoxin; Aspergillus flavus, peanuts; retailers; traditional market

\section{PENDAHULUAN}

Kacang tanah yang dijual di tingkat pengecer pada umumnya sudah dalam bentuk biji atau ose sehingga lebih rentan terinfeksi kapang penghasil aflatoksin (Rahmianna dkk., 2007a). Hasil penelitian Odoemelam dan Osu (2009), Amiri dkk. (2013) dan Riba dkk. (2013) menunjukkan bahwa konsentrasi aflatoksin yang terdeteksi pada kacang tanah relatif lebih tinggi daripada jenis kacang-kacangan lain. Cemaran aflatoksin pada kacang tanah di tingkat pengecer diketahui lebih tinggi daripada di tingkat petani (Dharmaputra dkk., 2007a; Rahmianna dkk., 2007a). Hal tersebut diduga sebagai hasil akumulasi cemaran yang terjadi mulai dari lahan hingga tahap transportasi dan penyimpanan di sepanjang rantai distribusi.

Kacang tanah yang beredar di wilayah Jakarta berasal dari wilayah lain, misalnya kacang tanah lokal yang sebagian besar berasal dari Tuban dan kacang tanah impor yang sebagian besar berasal dari India (Pusdatin, 2015; Swastika, 2015). Oleh sebab itu, kacang tanah di wilayah ini diperkirakan telah terinfeksi A. flavus dan tercemar aflatoksin. Pendistribusian kacang tanah yang semakin jauh dari sentra produksi dapat menyebabkan peningkatan cemaran $A$. flavus (Rahmianna dkk., 2007a) dan kapang tersebut dapat terbawa dari satu mata rantai distribusi ke mata rantai distribusi lainnya (Loreen dan Moses, 2015). Kacang tanah yang berasal dari wilayah lain juga berpotensi telah tercemar aflatoksin akibat proses pengiriman yang membutuhkan waktu beberapa hari serta faktor lingkungan seperti suhu, kelembaban dan curah hujan (Mutegi dkk., 2013a). Penelitian yang dilakukan oleh Dharmaputra dkk. (2007b) menunjukkan adanya infeksi A. flavus dan cemaran aflatoksin B1 (AFB1) yang lebih tinggi dari $15 \mathrm{ppb}$ pada kacang tanah impor yang diambil dari pelabuhan. Penelitian lain yang dilakukan oleh Dharmaputra dkk. (2010), menunjukkan kandungan AFB1 yang lebih besar dari $15 \mathrm{ppb}$ pada kacang tanah lokal dan impor di tingkat grosir dan pengecer di Jakarta.

Sebagian besar kacang tanah yang beredar pada pasar tradisional di wilayah Jakarta merupakan kacang tanah kupas kulit, yang ditempatkan dalam wadah terbuka selama proses penjualan. Penempatan kacang tanah dalam wadah terbuka dapat mempengaruhi peningkatan kadar air akibat terpapar suhu dan RH lingkungan, yang kemudian berdampak pada pertumbuhan kapang penghasil aflatoksin (Nakai dkk., 2008; Nyirahakizimana dkk., 2013; Rahmianna dan
Yusnawan, 2015). Pengecer kacang tanah di pasar tradisional umumnya juga merupakan penjual berbagai macam produk, baik pangan maupun non-pangan. Kios mereka dipenuhi berbagai komoditas sehingga sulit dibersihkan secara optimal. Kondisi area penyimpanan kacang tanah yang tidak bersih dapat memicu perkembangan kapang dan produksi aflatoksin (Mutegi dkk., 2013a).

Penelitian ini bertujuan mengidentifikasi dan mengevaluasi kondisi penyimpanan kacang tanah pada tingkat pengecer di DKI Jakarta, mengidentifikasi dan mengevaluasi perilaku pengecer dalam menyimpan kacang tanah dan mengidentifikasi potensi cemaran $A$. flavus pada kacang tanah. Pengecer yang dijadikan responden berjumlah 15 orang dan tersebar merata di 5 wilayah DKI Jakarta.

\section{METODE PENELITIAN}

Penelitian ini berupa studi kasus terhadap kondisi penyimpanan kacang tanah di tingkat pengecer yang berada di 5 wilayah kota administratif DKI Jakarta, yaitu Jakarta Pusat (JP), Jakarta Utara (JU), Jakarta Selatan (JS), Jakarta Barat (JB) dan Jakarta Timur (JT). Setiap kota administratif diwakili oleh 3 responden yang berasal dari 1 pasar tradisional terpilih. Pasar yang dipilih merupakan pasar yang dikelola oleh Pemda DKI Jakarta. Penelitian dilakukan dalam dua tahap. Tahap pertama berupa survei di area pengecer, yang meliputi wawancara mengenai cara dan kondisi penyimpanan, pengamatan langsung keadaan kios dan area penyimpanan, pengukuran suhu dan $\mathrm{RH}$ di area penyimpanan serta pengambilan sampel. Tahap kedua berupa analisis kadar air kacang tanah, penentuan persentase biji cacat dan penghitungan total kapang dan $A$. flavus.

\section{Bahan}

Kacang tanah kupas kulit atau biji kacang tanah, baik jenis lokal maupun impor (tergantung stok kacang tanah yang tersedia pada saat penelitian berlangsung), diambil dari wadah simpan maupun wadah jual di kios responden pengecer. Biji kacang tanah tersebut merupakan sampel utama dalam penelitian tahap kedua.

\section{Alat}

Kuesioner wawancara, alat ukur suhu dan RH digital (Yuwese DWL Series, Yuwese Sensor Co., Ltd, RRC), timbangan analitik (RADWAG WTB 200, RADWAG Wagi Elektroniczne, Polandia), blender (National, Panasonic Corporation, Jepang), kantung plastik HDPE, cawan 
porselen, oven (Memmert, Memmert GmbH + Co. KG, Jerman), alat-alat gelas, mikropipet, bunsen dan incubator (Fisher, Thermo Fisher Scientific Inc., AS).

\section{Penentuan Responden Pengecer}

Tiga pengecer kacang tanah dipilih dari 1 pasar tradisional yang masing-masing berada di 5 wilayah kota administratif DKI Jakarta (JP, JU, JS, JB dan JT), sehingga total responden adalah $15(n=15)$. Pemilihan responden berdasarkan metode purposive sampling, dengan persyaratan bahwa pengecer tersebut menjual kacang tanah langsung kepada konsumen, memiliki area penyimpanan di kiosnya, memiliki kapasitas jual antara 50-200 kg (1-4 karung) per kurun waktu 1-4 minggu dan bersedia untuk diwawancarai serta diamati kondisi kiosnya. Pembatasan jumlah responden terutama sebagai hasil pertimbangan bahwa tidak semua pengecer di satu pasar tradisional bersedia untuk diinvestigasi.

\section{Identifikasi dan Evaluasi Cara dan Kondisi Penyimpanan Kacang Tanah}

Identifikasi dilakukan melalui metode wawancara dengan kuesioner yang terdiri dari 20 pertanyaan. Hasil wawancara terkait perilaku responden dalam rutinitas pembersihan dan cara penyimpanan kacang tanah, yang disesuaikan dengan rekomendasi CAC (2004), kemudian diperingkat dengan pemberian skor (Tabel 1). Total skor tertinggi adalah 15 dan dianggap sebagai 100\% pencapaian kondisi yang baik. Evaluasi kesesuaian antara hasil wawancara dan keadaan faktual di lapang dilakukan dengan pengamatan langsung kondisi kios responden dan pengukuran suhu serta $\mathrm{RH}$ area penyimpanan. Pengukuran suhu dan RH dilakukan setiap 10 menit selama 1 jam. Rata-rata hasil pengukuran dibandingkan dengan kisaran suhu dan RH dari Badan Meteorologi, Klimatologi, dan Geofisika (BMKG) untuk wilayah DKI Jakarta di hari yang sama dengan saat kegiatan penelitian berlangsung.

\section{Penyediaan Sampel Kacang Tanah untuk Diuji}

Sampel sebanyak $500 \mathrm{~g}$ diambil secara langsung dari wadah simpan dan/atau wadah jual, lalu dikemas dalam kantung plastik HDPE dua lapis dan disimpan di dalam freezer sampai saat sebelum dianalisis. Total sampel yang diperoleh sebanyak 23 sampel, yaitu 4, 4, 4 , 6, dan 5, yang secara berurutan berasal dari responden di wilayah JP, JU, JS, JB dan JT. Metode penyiapan sampel berdasarkan metode quartering dari International Seed Testing Association (ISTA) (2016), dengan modifikasi pada cara pencampuran dan pembagian.

Pencampuran sampel kacang tanah dilakukan di atas tampah yang diberi lembaran kertas, dimana sampel tersebut dimampatkan secara manual (dengan tangan yang disarungi plastik) hingga menyerupai bidang lingkaran datar. Proses pencampuran dilakukan dengan penarikan setiap sisi kertas ke sisi di seberangnya secara bergantian. Hal tersebut dilakukan secara berurut dan berulang sebanyak 10 kali.

Sampel yang telah tercampur dibuat mengerucut dengan cara menarik keempat sudut kertas bersamaan hingga lembaran kertas tersebut berbentuk menyerupai kantung. Sampel yang mengerucut dimampatkan kembali hingga berbentuk bidang lingkaran datar, lalu dibagi merata menjadi empat dengan mistar. Dua bagian yang berseberangan disisihkan, dan sejumlah sampel yang akan dianalisis diambil dari dua bagian sisanya. Proses pembagian sampel dilanjutkan terhadap sampel yang tersisa dengan metode pembagian serupa.

\section{Analisis Kadar Air Kacang Tanah}

Analisis kadar air dilakukan pada $200 \mathrm{~g}$ sampel kacang tanah dengan metode oven berdasarkan SNI tentang cara uji makanan dan minuman (Dewan Standarisasi Nasional, 1992). Hasil analisis kadar air berupa data persentase berdasarkan bobot basah (bb).

Tabel 1. Pemberian skor terhadap perilaku responden dalam penyimpanan kacang tanah

\begin{tabular}{|c|c|c|c|}
\hline Perilaku & Kode & Pilihan jawaban & Skor \\
\hline \multirow[t]{3}{*}{ Frekuensi pembersihan langit-langit kios } & $A$ & Tidak pernah/tidak tentu & 1 \\
\hline & & Jarang & 2 \\
\hline & & Setiap hari & 3 \\
\hline \multirow[t]{3}{*}{ Frekuensi pembersihan lantai kios } & B & Tidak pernah/tidak tentu & 1 \\
\hline & & Jarang & 2 \\
\hline & & Setiap hari & 3 \\
\hline \multirow{2}{*}{$\begin{array}{l}\text { Penempatan wadah simpan di atas palet atau } \\
\text { pemberian lapisan tahan air di antara } \\
\text { wadah simpan dan lantai }\end{array}$} & $\mathrm{C}$ & Tidak pernah & 1 \\
\hline & & Selalu & 3 \\
\hline \multirow[t]{2}{*}{ Pencampuran kacang tanah lama dan baru } & $\mathrm{D}$ & Tidak pernah & 3 \\
\hline & & Selalu & 1 \\
\hline \multirow[t]{2}{*}{ Pemilahan biji kacang tanah cacat } & $E$ & Tidak pernah & 1 \\
\hline & & Selalu & 3 \\
\hline
\end{tabular}




\section{Penentuan Persentase Biji Cacat}

Komponen biji cacat adalah biji rusak, biji keriput dan biji belah. Definisi dari masing-masing biji tersebut diperoleh dari SNI tentang Kacang Tanah (Dewan Standarisasi Nasional, 1995). Biji rusak adalah biji kacang tanah yang berlubang bekas serangan hama, pecah karena mekanis, biologis, fisis dan enzimatis, seperti kecambah, busuk, bau tidak disukai, berubah warna maupun bentuk. Biji keriput adalah biji kacang tanah yang berubah bentuknya dan keriput, termasuk biji sangat muda dan atau tidak sempurna pertumbuhannya. Biji belah adalah biji kacang tanah yang kulit bijinya terlepas dan keping-keping bijinya terlepas atau tergeser. Jumlah sampel yang digunakan adalah $100 \mathrm{~g}$. Persentase dari biji cacat ditetapkan dengan Persamaan 1.

$\%$ Kondisi fisik biji: $\frac{\text { Berat biji dengan kondisi fisik tertentu }}{\text { Berat seluruh sampel analisis }} \times 100 \%$

\section{Penentuan dan Penghitungan Total Kapang dan A. flavus}

Penentuan dan penghitungan total kapang dan kapang $A$. flavus dilakukan dengan metode dari Bacteriological Analytical Manual (BAM) (Tournas dkk., 2001) dan menggunakan media agar selektif Aspergillus flavus and parasiticus Agar (AFPA) (Pitt dkk., 1983). Sampel yang diambil dari tiap wilayah hanya 2 jenis, yaitu kacang tanah lokal dan kacang tanah impor $(n=10)$, dan diperoleh dari responden yang berbeda sehingga setiap wilayah diwakili oleh 2 responden. Sampel dari tiap responden merupakan salah satu jenis kacang tanah, yaitu kacang tanah lokal saja atau kacang tanah impor saja. Sampel yang diprioritaskan bagi penentuan dan penghitungan total kapang serta $A$. flavus adalah sampel yang mewakili salah satu asal kacang tanah (lokal atau impor), sampel dengan persentase biji cacat yang relatif lebih tinggi dan sampel yang berasal dari area penyimpanan. Jumlah kacang tanah yang diuji untuk setiap sampel adalah $100 \mathrm{~g}$ dan digunakan sebagai 2 ulangan. Setiap ulangan diuji secara duplo.

Sampel sebanyak $50 \mathrm{~g}$ dihancurkan dengan blender dan ditambah $450 \mathrm{~mL}$ larutan buffer pepton $0,1 \%$, sehingga diperoleh larutan dengan pengenceran 1:10. Larutan dikocok secara manual selama 1 menit. Pengenceran dilanjutkan hingga 1:1000 dengan pengambilan $1 \mathrm{~mL}$ larutan dari pengenceran terendah ke dalam $9 \mathrm{~mL}$ larutan buffer pepton $0,1 \%$ di dalam tabung reaksi. Larutan sampel dari tiap pengenceran lalu dipipet sebanyak 0,1 mL secara aseptis dan dituang ke atas permukaan media AFPA yang telah mengeras di dalam cawan petri. Sampel disebar dan diratakan ke seluruh permukaan agar dengan hockey stick spreader hingga terserap. Sampel dalam cawan kemudian diinkubasi dalam incubator pada suhu $30{ }^{\circ} \mathrm{C}$ selama 48 jam. Kapang $A$. flavus ditunjukkan oleh koloni yang memiliki miselium berwarna putih, spora kekuningan dan bagian bawah yang berwarna oranye pada media AFPA.

\section{Analisis Statistik}

Analisis Ragam (ANOVA) dan uji lanjut WallerDuncan pada taraf signifikasi $5 \%$ dengan program IBM SPSS Statistic 24 digunakan untuk menguji perbedaan rata-rata hasil pengukuran suhu, RH dan kadar air serta persentase biji cacat.

\section{Uji Korelasi}

Uji korelasi Pearson Product-Moment pada taraf signifikasi $5 \%$ digunakan untuk mengetahui nilai koefisien korelasi $(r)$ dan tingkat hubungan antara ratarata total kapang dan $A$. flavus dengan rata-rata pengukuran suhu, $\mathrm{RH}$, kadar air, perilaku pengecer dan persentase biji cacat.

\section{HASIL DAN PEMBAHASAN}

\section{Cara dan Kondisi Penyimpanan di Tingkat Pengecer}

Bentuk bangunan pasar tradisional yang dikelola oleh Pemerintah Daerah DKI Jakarta umumnya berupa gedung bertingkat (2-3 lantai) dan semi terbuka. Kioskios di dalam pasar berupa ruang dengan ukuran $2,5 \times$ $2,5 \times 2,5 \mathrm{~m}^{3}$ dengan bukaan pada satu sisi sebagai pintu masuk dengan rolling door. Kios tidak berventilasi dan aliran udara diperkirakan bersikulasi melalui koridor. Kondisi kios seluruh responden cenderung serupa, yaitu berupa toko yang menjual berbagai jenis produk, baik pangan maupun non-pangan, sehingga area penjualan dan penyimpanan dipenuhi berbagai komoditas (Gambar 1). Karakteristik responden beserta cara dan kondisi penyimpanan kacang tanah tersaji pada Tabel 2 dan Tabel 3.

Kacang tanah yang beredar pada pasar-pasar tradisional di Jakarta berasal dari wilayah lain, dan telah melalui beberapa tahap transportasi serta penyimpanan, mulai dari gudang petani atau produsen hingga ke gudang agen. Menurut Mutegi dkk. (2013a), akumulasi cemaran aflatoksin pada kacang tanah dapat disebabkan oleh lamanya masa simpan, kondisi area penyimpanan tidak layak, serta faktor lingkungan seperti suhu, kelembaban dan curah hujan.

Masa simpan kacang tanah pada penelitian ini dapat diartikan sebagai lamanya keberadaan komoditas tersebut di kios responden hingga habis terjual. Setiap 1 karung kacang tanah umumnya habis terjual dalam kurun waktu 7 hari. Responden membatasi stok kacang tanah yang disimpan berdasarkan lama penjualan. Menurut pengalaman mereka, kacang tanah yang terlalu lama disimpan atau terlalu lama habis terjual akan berkutu, berulat serta berkapang sehingga dapat mempengaruhi harga jual kacang tanah. 


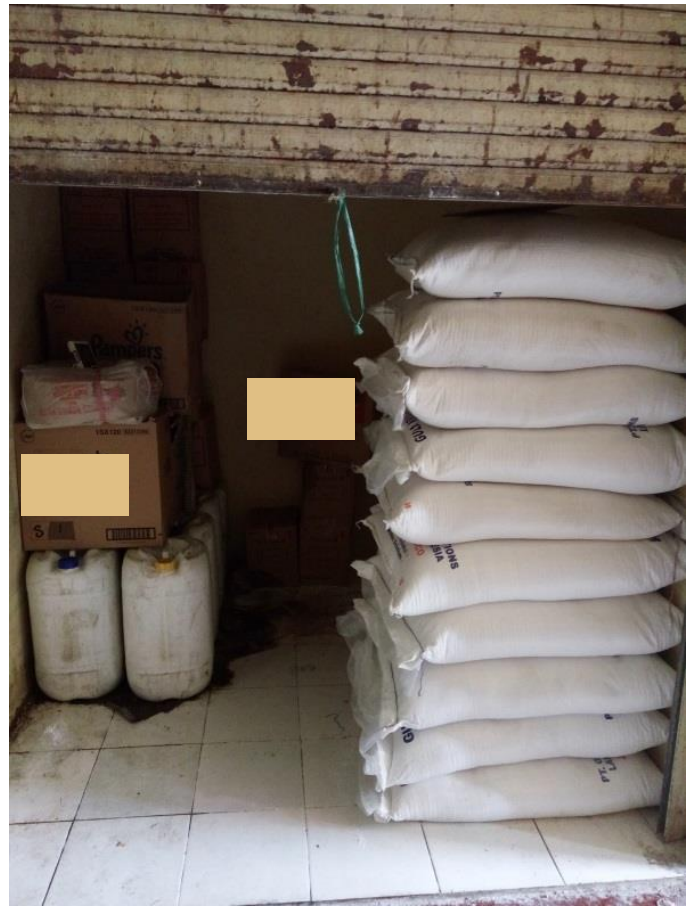

(a)

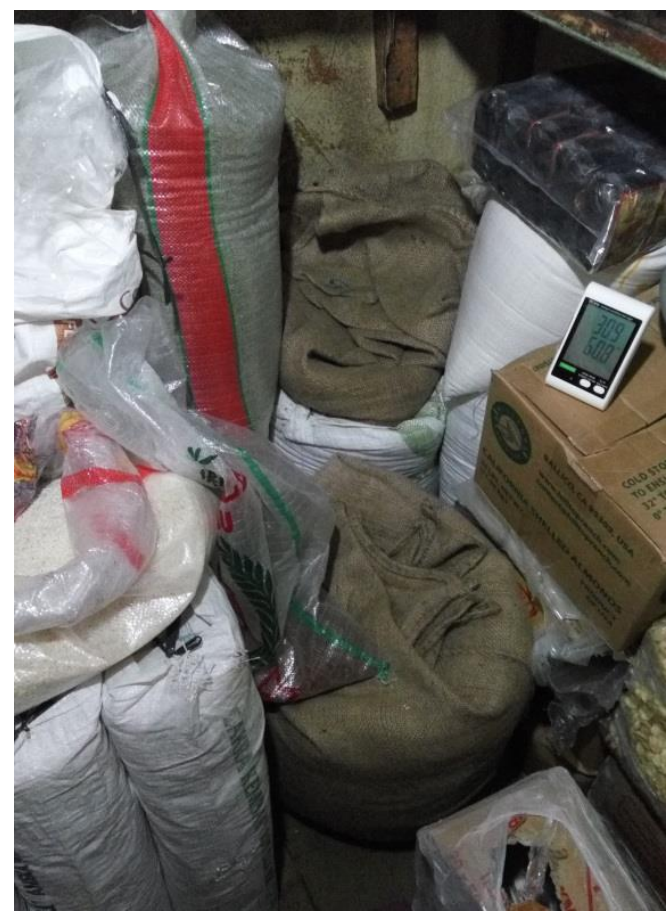

(b)

Gambar 1. (a) contoh penampakan kios pengecer (JU1) dari luar yang dijadikan area penyimpanan atau gudang dengan berbagai komoditas di dalamnya seperti gula pasir, minyak goreng dan komoditas non-pangan (pada saat kegiatan penelitian berlangsung, stok kacang tanah di gudang sudah habis dan sedang dalam proses pengiriman dari pemasok); (b) contoh penampakan kios pengecer (JB2) dari dalam dengan keberadaan stok kacang tanah dalam karung goni yang diletakkan langsung di atas lantai dan juga ditumpuk di atas komoditas lainnya.

Perilaku responden baru memenuhi $47-80 \%$ kondisi yang direkomendasikan oleh CAC (Tabel 3), sehingga masih terdapat perilaku atau kebiasaan yang dapat memicu perkembangan kapang. Kegiatan pembersihan kios tidak dapat dilakukan secara rutin dan optimal, terutama pada bagian langit-langit (kode A, Tabel 3) karena kios dipenuhi berbagai komoditas. Terdapat sarang laba-laba yang ditempeli debu pada langit-langit kios seluruh responden. Pembersihan lantai (kode B, Tabel 3) relatif lebih sering dilakukan keadaan lantai kios tidak sepenuhnya bersih karena pembersihan hanya dilakukan pada area yang tidak ada tumpukan komoditas. Kotoran pada lantai berupa kerak dari debu atau tanah yang menempel. Kerak kotoran relatif lebih banyak pada lantai yang dilapisi tegel. Penggunaan keramik umumnya dijumpai pada bangunan pasar yang terbilang baru dalam pendiriannya.

Kacang tanah yang disimpan pada area yang tidak bersih, berdebu dan tidak berventilasi dapat memicu kontaminasi aflatoksin lebih jauh (Mutegi dkk., 2013a). Aflatoksin merupakan metabolit sekunder dari kapang A. flavus. Kapang tersebut mendominasi populasi

Tabel 2. Asal kacang tanah, kondisi kios, dan cara penyimpanan kacang tanah

\begin{tabular}{|c|c|c|c|c|c|}
\hline Resp. & $\begin{array}{c}\text { Asal kacang } \\
\text { tanah }\end{array}$ & Langit-langit & Lantai & Wadah simpan & $\begin{array}{c}\text { Masa } \\
\text { simpan } \\
\text { (hari) }\end{array}$ \\
\hline JP1 & Lokal \& Impor & Gipsum & Keramik & Karung goni & $7-14$ \\
\hline JP2 & Impor & Gipsum & Keramik & Karung goni & 7 \\
\hline JP3 & Impor & Gipsum & Keramik & Karung plastik & 2 \\
\hline JU1 & Impor & Lapisan semen & Keramik & Karung goni & 7 \\
\hline JU2 & Tidak tahu & Lapisan semen & Keramik & Karung goni & 4 \\
\hline JU3 & Impor & Lapisan semen & Keramik & Karung goni & 7 \\
\hline JS1 & Impor & Lapisan semen & Tegel & Karung goni & 14 \\
\hline JS2 & Lokal & Lapisan semen & Tegel & Karung goni & 7 \\
\hline JS3 & Lokal & Lapisan semen & Tegel & Karung goni & 7 \\
\hline $\mathrm{JB} 1$ & Tidak tahu & Lapisan semen & Tegel & Karung goni & $7-30$ \\
\hline $\mathrm{JB} 2$ & Impor & Lapisan semen & Tegel & Karung goni \& plastik & $3-7$ \\
\hline JB3 & Impor & Lapisan semen & Lapisan semen & Karung goni & $14-30$ \\
\hline $\mathrm{JT} 1$ & Lokal \& Impor & Lapisan semen & Tegel & Karung goni & 7 \\
\hline JT2 & Lokal \& Impor & Lapisan semen & Keramik & Karung goni & 7 \\
\hline JT3 & Lokal \& Impor & Kayu & Tegel & Karung goni & 7 \\
\hline
\end{tabular}


kapang di tanah (Mohammadi dkk., 2009; Zhang dkk., 2017) dan dikenal juga sebagai storage fungi (Khosravi dkk., 2007; Nakai dkk., 2008). Hal itu menyebabkan kacang tanah rentan terhadap cemaran dan akumulasi aflatoksin apabila kondisi saat di lahan hingga tahap penyimpanan dapat mendukung perkembangan $A$. flavus dan produksi aflatoksin. Selain kegiatan pembersihan kios yang tidak rutin dan optimal, responden juga cenderung menempatkan wadah simpan secara langsung di lantai dan tidak terbiasa memilah biji cacat (kode $\mathrm{C}$ dan $\mathrm{E}$, Tabel 3).

Sebagian besar wadah simpan kacang tanah berupa karung goni. Wadah tersebut merupakan pengemas yang digunakan selama transportasi dan penyimpanan sebelum kacang tanah sampai ke pengecer. Penggunaan karung goni direkomendasikan sebagai pengemas untuk penyimpanan karena terbuat dari bahan yang tidak menghambat aliran udara, walaupun jenis pengemas tersebut mudah menyerap uap air dari lingkungan di sekitarnya (Mutegi dkk., 2013b). Wadah simpan diletakkan langsung di atas lantai pada area yang masih tersedia atau ditumpuk di atas komoditas lainnya. Penyediaan lapisan di atas lantai oleh responden umumnya berupa lembaran dari kardus. Bahan tersebut masih dapat ditembus air serta berpotensi sebagai sumber cemaran jika tidak rutin dibersihkan atau diganti.

Pemilahan biji kacang tanah cacat tidak pernah dilakukan oleh seluruh responden sehingga keberadaannya masih dapat ditemui pada setiap sampel. Menurut responden, selama ini tidak ada tuntutan dari konsumen untuk memperoleh kacang tanah yang bebas biji cacat. Selain itu, kebijakan atau peraturan terkait mutu kacang tanah belum wajib diberlakukan di Indonesia. SNI Kacang Tanah yang berlaku saat ini masih berupa himbauan yang dapat diikuti secara sukarela (Ginting dkk., 2015). Berdasarkan penelitian yang dilakukan oleh N'dede dkk. (2012), para pelaku pasar tidak akan melakukan pemilahan biji, kecuali mereka memperoleh harga yang lebih tinggi bagi komoditas yang mereka jual. Pemilahan biji cacat memang dapat berdampak pada konsumsi waktu, penurunan kapasitas penjualan dan peningkatan biaya serta harga jual (N'dede dkk., 2012; Guchi, 2015).

Rekomendasi CAC bagi penyimpanan biji kacang tanah adalah aktivitas air (aw) produk kurang dari 0,7, $\mathrm{RH}$ ruangan di bawah $70 \%$ dan suhu antara $0-10{ }^{\circ} \mathrm{C}$, sebab pada kondisi tersebut kapang $A$. flavus atau $A$. parasiticus tidak dapat tumbuh atau memproduksi aflatoksin. Kisaran suhu yang direkomendasikan CAC hanya dapat tercapai jika menggunakan fasilitas penyimpanan dingin (cold storage). Penyimpanan kacang tanah pada suhu rendah $\left(24-28{ }^{\circ} \mathrm{C}\right)$ pernah diterapkan pada penelitian Rahmianna dkk. (2007b) berdasarkan rekomendasi Indonesian Legumes and Tuber Crops Research Institute (ILETRI). Hasil penelitian menunjukkan bahwa frekuensi cemaran aflatoksin B1 pada kacang tanah yang disimpan pada suhu tersebut lebih rendah daripada kacang tanah yang disimpan pada suhu ruang $\left(25-35^{\circ} \mathrm{C}\right)$.

Rata-rata suhu yang terukur dari area penyimpanan di tiap wilayah $\left(29,6-31,2^{\circ} \mathrm{C}\right)$ merupakan suhu ruang dan lebih tinggi dari kisaran suhu yang direkomendasikan oleh CAC serta ILETRI. Kisaran suhu tersebut umum dijumpai pada negara-negara tropis dan sesuai bagi pertumbuhan $A$. flavus serta produksi aflatoksin (OBrian dkk., 2007; Singh dan Chauhan, 2013; Pratiwi dkk., 2015). Berkebalikan dengan hal tersebut, sebagian besar rata-rata $\mathrm{RH}$ yang terukur dari tiap wilayah $(53,6-73,1 \%)$ sesuai dengan rekomendasi

Tabel 3. Skor perilaku responden, rata-rata suhu dan RH area penyimpanan serta kadar air biji kacang tanah

\begin{tabular}{|c|c|c|c|c|c|c|c|c|c|}
\hline \multirow[b]{2}{*}{ Responden } & \multicolumn{6}{|c|}{ Skor* } & \multicolumn{3}{|c|}{ Rata-rata** } \\
\hline & $A$ & B & C & $\mathrm{D}$ & $E$ & Total (persentase) & Suhu $\left({ }^{\circ} \mathrm{C}\right)$ & $\mathrm{RH}(\%)$ & $\begin{array}{l}\text { Kadar air (\%), } \\
\mathrm{n}=200 \mathrm{~g}\end{array}$ \\
\hline JP1 & 1 & 3 & 1 & 3 & 1 & $9(60 \%)$ & $29,6 \pm 0,5^{a}$ & $67,4 \pm 1,2^{\text {ef }}$ & $6,2 \pm 0,2^{a}$ \\
\hline JP2 & 1 & 3 & 1 & 3 & 1 & $9(60 \%)$ & $30,3 \pm 0,1^{b}$ & $66,2 \pm 0,7$ de & $6,8 \pm 0,2^{\mathrm{bcd}}$ \\
\hline JP3 & 1 & 3 & 1 & 3 & 1 & $9(60 \%)$ & $30,8 \pm 0,1^{\text {bcde }}$ & $62,8 \pm 0,7 c$ & $6,9 \pm 0,2^{\text {cde }}$ \\
\hline JU1 & 1 & 3 & 1 & 3 & 1 & $9(60 \%)$ & $30,8 \pm 0,5^{\text {bcde }}$ & $67,7 \pm 0,8^{\text {ef }}$ & $6,4 \pm 0,4^{\mathrm{ab}}$ \\
\hline JU2 & 1 & 1 & 1 & 3 & 1 & $7(47 \%)$ & $30,7 \pm 0,2^{\text {bcde }}$ & $70,0 \pm 0,6^{9}$ & $6,6 \pm 0,5^{\mathrm{abcd}}$ \\
\hline JU3 & 1 & 1 & 1 & 3 & 1 & $7(47 \%)$ & $31,1 \pm 0,7$ de & $68,1 \pm 1,2^{f}$ & $7.0 \pm 0,3^{\text {de }}$ \\
\hline JS1 & 1 & 3 & 1 & 3 & 1 & $9(60 \%)$ & $30,9 \pm 1,2^{\text {bcde }}$ & $66,6 \pm 2,8^{\text {ef }}$ & $6,7 \pm 0,4^{\mathrm{abcd}}$ \\
\hline JS2 & 1 & 3 & 1 & 3 & 1 & $9(60 \%)$ & $30,5 \pm 0,3^{\text {bcde }}$ & $67,7 \pm 0,9^{\text {ef }}$ & $6,7 \pm 0,5^{\mathrm{abcd}}$ \\
\hline JS3 & 1 & 3 & 1 & 3 & 1 & $9(60 \%)$ & $30,4 \pm 0,2^{b c}$ & $64,5 \pm 1,2^{\text {cd }}$ & $6,8 \pm 0,2^{\mathrm{bcd}}$ \\
\hline JB1 & 1 & 3 & 1 & 3 & 1 & $9(60 \%)$ & $31,0 \pm 0,4^{\text {de }}$ & $64,8 \pm 1,3^{d}$ & $6,5 \pm 0,1^{\mathrm{abcd}}$ \\
\hline $\mathrm{JB} 2$ & 1 & 3 & 1 & 3 & 1 & $9(60 \%)$ & $31,0 \pm 0,4^{\text {cde }}$ & $61,0 \pm 0,9^{b}$ & $6,5 \pm 0,3^{\mathrm{abc}}$ \\
\hline JB3 & 1 & 1 & 1 & 3 & 1 & $7(47 \%)$ & $31,2 \pm 0,2^{e}$ & $53,6 \pm 1,4^{a}$ & $6,9 \pm 0,3^{\text {cde }}$ \\
\hline JT1 & 2 & 3 & 3 & 3 & 1 & $12(80 \%)$ & $30,8 \pm 0,1^{\text {bcde }}$ & $72,9 \pm 1,9^{h}$ & $7,9 \pm 0,1^{f}$ \\
\hline JT2 & 1 & 3 & 1 & 3 & 1 & $9(60 \%)$ & $31,2 \pm 0,1^{e}$ & $73,1 \pm 0,3^{h}$ & $7,4 \pm 0,2^{\text {ef }}$ \\
\hline JT3 & 1 & 3 & 1 & 3 & 1 & $9(60 \%)$ & $30,5 \pm 0,1^{\text {bcd }}$ & $72,9 \pm 0,7^{\mathrm{h}}$ & $7,4 \pm 0,2^{\mathrm{e}}$ \\
\hline
\end{tabular}

*A (frekuensi pembersihan langit-langit), B (frekuensi pembersihan lantai), C (penempatan wadah simpan), D (pencampuran kacang tanah), E (pemilahan biji cacat); **uji beda rata-rata dengan ANOVA dan uji lanjut Waller-Duncan, data pada satu kolom dengan huruf yang sama tidak berbeda secara signifikan $(p>0,05)$ 
CAC dan masih di bawah nilai optimum bagi pertumbuhan $A$. flavus serta produksi aflatoksin (Shehu dan Bello, 2011; Pratiwi dkk., 2015).

Pengukuran suhu dan RH di tiap wilayah dilakukan pada waktu yang berbeda, yaitu di antara bulan JuliAgustus. Berdasarkan data BMKG (2016), kisaran suhu dan $\mathrm{RH}$ dalam rentang waktu tersebut masing-masing adalah $23-34{ }^{\circ} \mathrm{C}$ dan $63-97 \%$. Area penyimpanan kacang tanah terpapar suhu dan RH lingkungan selama kios dibuka, termasuk pada saat kegiatan penelitian berlangsung, sehingga rata-rata suhu dan $\mathrm{RH}$ yang terukur masih dalam kisaran BMKG.

Nilai rata-rata $\mathrm{RH}$ di wilayah JT cenderung lebih tinggi dari rekomendasi CAC, sementara itu nilai ratarata $\mathrm{RH}$ di wilayah JB cenderung lebih rendah dari kisaran BMKG (Tabel 3). Hal tersebut dapat disebabkan oleh perbedaan lokasi kios di dalam bangunan pasar. Seluruh kios responden di wilayah JT berada pada area basement sehingga uap air di area itu kemungkinan terperangkap karena sirkulasi udara yang terbatas. Sementara itu, seluruh kios responden di wilayah JB berada di lantai dua dan salah satu kios berada dekat dengan sisi terluar bangunan pasar sehingga aliran udara yang bersikulasi di tempat itu relatif lebih tinggi. Pada penelitian ini tidak dilakukan pengukuran aliran udara, namun berdasarkan penelitian yang dilakukan oleh (Rostami dkk. (2009), adanya aliran udara berbanding terbalik dengan $\mathrm{RH}$.

Nilai rata-rata KA yang terukur dari tiap wilayah berada di bawah 7\%, kecuali pada wilayah JT. Nilai tersebut masih dalam lingkup yang ditetapkan oleh SNI (Dewan Standarisasi Nasional, 1995) dan serupa dengan hasil penelitian Dharmaputra dkk. terhadap kacang tanah impor $(6-7 \%)$ serta lokal dan impor (6-8\%) di tingkat grosir dan pengecer di Jakarta (Dharmaputra dkk., 2007b; 2010). Rata-rata KA berkorelasi positif dengan rata-rata $\mathrm{RH}$ area penyimpanan $(r=0,45)$. Menurut Dharmaputra dkk. (2007b), aw biji kacang tanah berkorelasi positif dengan kadar air, dan kadar air biji kacang tanah meningkat dengan semakin meningkatnya RH selama penyimpanan. Peningkatan kadar air kacang tanah akibat peningkatan $\mathrm{RH}$ area penyimpanan atau lingkungan dapat dipicu oleh penggunaan karung goni sebagai wadah simpan. Penyimpanan kacang tanah di dalam karung goni berkontribusi terhadap penyerapan uap air dari lingkungan (Mutegi dkk., 2013b).

\section{Keberadaan Biji Cacat dan Kapang A, flavus}

Biji cacat pada sampel didominasi oleh biji rusak dan biji keriput. Biji rusak yang ditemui berupa biji yang berkecambah, rusak/patah serta mengalami perubahan warna. Biji berlubang, berulat dan berkapang juga ditemui pada beberapa sampel, terutama sampel yang disimpan relatif lebih lama daripada sampel lainnya. Berdasarkan hasil temuan, biji berlubang disebabkan oleh aktivitas ulat yang mengurai biji kacang tanah. Rata-rata biji rusak, biji keriput dan biji belah dari setiap responden tersaji pada Tabel 4.

Persentase biji cacat, terutama biji rusak dan biji keriput, melebihi batas maksimum persyaratan yang telah ditetapkan oleh SNI Kacang Tanah. Hal tersebut tergambar dari perilaku responden pengecer yang tidak terbiasa melakukan pemilahan biji sehingga keberadaan biji cacat atau parameter lainnya yang tidak memenuhi persyaratan masih dapat ditemui pada kacang tanah yang dijual eceran.

Keberadaan biji cacat sudah ada pada komoditas kacang tanah sebelum sampai di tingkat pengecer (Ginting dan Rahmianna, 2015). Cacat pada biji dapat terjadi mulai dari lahan hingga proses penanganan pascapanen, seperti proses pemanenan lebih awal yang dapat mengakibatkan biji keriput serta kerusakan pada saat pengupasan polong yang dapat memicu kontaminasi kapang (Dharmaputra dkk., 2013). Persentase biji cacat di tiap wilayah yang cenderung tidak berbeda secara signifikan $(p>0,05)$ mengindikasikan cara dan kondisi pascapanen, termasuk transportasi dan penyimpanan, relatif tidak

Tabel 4. Rata-rata persentase biji cacat, total kapang dan A. flavus

\begin{tabular}{|c|c|c|c|c|c|}
\hline \multirow{2}{*}{ Responden } & \multicolumn{3}{|c|}{ Rata-rata* persentase biji cacat (\%), $\mathrm{n}=100 \mathrm{~g}$} & \multicolumn{2}{|c|}{ Rata-rata (Log cfu/g) } \\
\hline & Rusak & Keriput & Belah & Total kapang & A. flavus \\
\hline JP1 & $7,0 \pm 0,1^{\mathrm{abc}}$ & $15,0 \pm 10,2^{a b c}$ & $4,2 \pm 3,8^{\mathrm{abc}}$ & $3,5 \pm 0,2^{1)}$ & $2,6 \pm 0,1^{1)}$ \\
\hline JP2 & $6.0 \pm 0,8^{\mathrm{abc}}$ & $14,5 \pm 3,7 \mathrm{abc}$ & $5,0 \pm 2,2^{\mathrm{bcd}}$ & - & - \\
\hline JP3 & $4,8 \pm 0,4^{\mathrm{ab}}$ & $32,3 \pm 2,6^{d}$ & $2,0 \pm 0,7^{a b}$ & $\left.2,5 \pm 0,1^{2}\right)$ & $<1,0 \pm 0,0^{2)}$ \\
\hline JU1 & $7,4 \pm 0,3^{\mathrm{abc}}$ & $18,7 \pm 0,1^{\text {abcd }}$ & $3,6 \pm 0,6 \mathrm{abc}$ & - & - \\
\hline JU2 & $3,9 \pm 0,1^{a}$ & $8,2 \pm 0,6^{a}$ & $0,2 \pm 0,0^{a}$ & $\left.4,1 \pm 0,5^{2}\right)$ & $\left.2,1 \pm 0,2^{2}\right)$ \\
\hline JU3 & $6,6 \pm 1,1^{\mathrm{abc}}$ & $17,7 \pm 4,6^{a b c}$ & $3,5 \pm 0,5^{\mathrm{abc}}$ & $4,7 \pm 0,7^{2)}$ & $\left.1,6 \pm 0,9^{2}\right)$ \\
\hline JS1 & $4,9 \pm 2,4^{a b}$ & $8,2 \pm 5,7^{a}$ & $5,7 \pm 2,4^{\mathrm{bcd}}$ & $\left.3,2 \pm 0,1^{2}\right)$ & $\left.2,5 \pm 0,0^{2}\right)$ \\
\hline JS2 & $6,6 \pm 1,9 a b c$ & $5,4 \pm 1,5^{a}$ & $8,8 \pm 0,9^{d}$ & - & - \\
\hline JS3 & $5,2 \pm 1,6^{\mathrm{ab}}$ & $24,4 \pm 0,1^{\mathrm{cd}}$ & $3,2 \pm 0,2^{\mathrm{abc}}$ & $2,5 \pm 0,5^{1)}$ & $<1,0 \pm 0,0^{1)}$ \\
\hline JB1 & $19,1 \pm 8,2^{d}$ & $22,9 \pm 7,8^{\mathrm{bcd}}$ & $3,7 \pm 2,8^{a b c}$ & - & - \\
\hline JB2 & $12,5 \pm 1,2^{\text {cd }}$ & $14,3 \pm 9,0^{a b c}$ & $6,0 \pm 2,3^{\mathrm{bcd}}$ & $5,6 \pm 0,2^{2)}$ & $<1,0 \pm 0,0^{2)}$ \\
\hline JB3 & $11,3 \pm 2,6^{b c}$ & $10,3 \pm 2,4^{a b}$ & $7,6 \pm 2,4^{\mathrm{cd}}$ & $4,3 \pm 0,3^{1)}$ & $2,5 \pm 0,1^{1)}$ \\
\hline JT1 & $10,5 \pm 2,1^{\mathrm{abc}}$ & $18,2 \pm 2,6^{a b c}$ & $3,2 \pm 3,6^{a b c}$ & $5,6 \pm 0,2^{2)}$ & $\left.1,3 \pm 0,5^{2}\right)$ \\
\hline JT2 & $8,3 \pm 3,4^{\mathrm{abc}}$ & $16,1 \pm 3,9^{a b c}$ & $1,5 \pm 0,8^{\mathrm{ab}}$ & $5,2 \pm 0,3^{1)}$ & $4,0 \pm 2,1^{1)}$ \\
\hline JT3 & $5,5 \pm 3,2^{\mathrm{ab}}$ & $11,0 \pm 10,9^{a b c}$ & $6,1 \pm 1,2^{\mathrm{bcd}}$ & - & - \\
\hline
\end{tabular}

*Uji beda rata-rata dengan ANOVA dan uji lanjut Waller-Duncan; data pada satu kolom dengan huruf yang sama tidak berbeda secara signifikan $(p>0,05) ;{ }^{1)}$ kacang tanah lokal; ${ }^{2}$ kacang tanah impor 
berbeda di antara para pemasok di sepanjang rantai distribusi.

Sebagian besar persentase biji rusak relatif lebih rendah daripada biji keriput (Tabel 4), dan berbeda dengan hasil yang diperoleh dari penelitian Dharmaputra dkk. (2013) serta Ginting dan Rahmianna (2015). Hal tersebut dapat disebabkan oleh perbedaan asal kacang tanah. Biji kacang tanah dari dua penelitian tersebut berasal dari sentra produksi di dalam negeri, sementara sebagian besar kacang tanah yang dijual oleh pengecer di Jakarta berasal dari luar negeri (impor). Keberadaan biji rusak yang relatif lebih tinggi dari kedua penelitian sebelumnya disebabkan oleh pengupasan polong yang tidak layak (Dharmaputra dkk., 2013) dan waktu panen yang tidak tepat (Ginting dan Rahmianna, 2015). Penanganan panen dan pascapenen kacang tanah yang belum terstandar pada akhirnya berdampak pada mutu biji. Namun demikian, rata-rata persentase biji rusak pada penelitian ini, baik dari sampel kacang tanah lokal maupun impor, tidak berbeda nyata (kecuali sampel dari wilayah JB). Biji kacang tanah lokal yang beredar di wilayah Jakarta diduga merupakan biji bermutu baik. Hal tersebut juga didukung oleh harga jual kacang tanah lokal yang relatif lebih tinggi dari kacang tanah impor.

Rata-rata persentase biji rusak di wilayah JB relatif lebih tinggi daripada wilayah lainnya. Ketiga responden di wilayah tersebut memasok kacang tanah dari pemasok yang sama. Mutu kacang tanah dari pemasok tersebut diperkirakan relatif lebih rendah daripada pemasok lainnya. Sementara itu, rata-rata persentase biji keriput dari salah satu responden di wilayah JP dan JS relatif lebih tinggi. Berdasarkan hasil wawancara, kedua responden tersebut terbiasa memasok kacang tanah dengan harga terendah. Biji kacang tanah berukuran kecil dan keriput umumnya dijual dengan harga murah.

Koloni kapang terdeteksi pada seluruh sampel kacang tanah terpilih, dengan kisaran rata-rata total koloni antara 2,5-5,6 log cfu/g. Sementara itu, kapang $A$. flavus terdeteksi di antara koloni kapang pada $70 \%$ sampel terpilih, dengan rata-rata koloni antara 1,3-4,0 log cfu/g. Sampel dengan rata-rata koloni $A$. flavus tertinggi berasal dari wilayah JT (4,0 log cfu/g). Koloni A. niger, yang termasuk kapang Aspergillus golongan Nigri (Perrone dkk., 2007; Mohammadi dkk., 2009), juga terdeteksi pada $90 \%$ sampel, dengan rata-rata koloni antara 1,3-4,5 log cfu/g (data tidak ditampilkan). Kapang lain yang terdeteksi diperkirakan sebagai Penicillium berdasarkan penampakan morfologinya.
Keberadaan kapang tersebut terdeteksi pada $30 \%$ sampel (data tidak ditampilkan). Dominasi kapang Aspergillus pada kacang tanah juga dilaporkan dalam penelitian Khodavaisy dkk. (2012) serta Mohammed dan Chala (2014).

Keberadaan kapang Aspergillus dan Penicillium relatif lebih tinggi pada sampel yang berasal dari wilayah JT. Kedua kapang tersebut merupakan storage fungi yang dapat ditemukan pada komoditas kacang tanah yang disimpan (Khosravi dkk., 2007; Nakai dkk., 2008; Ding dkk., 2015; Santos dkk., 2016) dan merupakan mikroorganisme yang umumnya terdapat dalam suatu ruangan tertutup atau indoor area (Yassin dan Almouqatea, 2010; Singh dan Chauhan, 2013). Peningkatan $\mathrm{RH}$ dan kondisi penyimpanan yang tidak layak dapat memicu perkembangan kedua kapang tersebut (Nakai dkk., 2008; Khodavaisy dkk., 2012). Hal itu sesuai dengan keadaan kios di wilayah JT yang berada di area basement, dengan RH yang relatif lebih tinggi (Tabel 3), serta kecenderungan responden dalam meletakkan wadah simpan secara langsung di atas lantai sehingga rentan terpapar kotoran dan debu.

Sampel yang tidak ditumbuhi $A$. flavus di wilayah JP dan JS merupakan sampel dengan keberadaan total kapang yang relatif lebih rendah (2.5 log cfu/g) dan keberadaan biji keriput yang relatif lebih tinggi. Hubungan yang berkebalikan tersebut dapat menjadi salah satu indikasi bahwa biji keriput relatif tidak serentan biji rusak dalam terinfeksi kapang. Hasil serupa diperoleh dari penelitian Rahmianna dkk. (2007a), yaitu biji keriput berkorelasi negatif dengan tingkat infeksi $A$. flavus $(r=-0,338)$.

\section{Potensi Keberadaan A. flavus}

Hasil uji korelasi antara kondisi penyimpanan dan keberadaan kapang dapat dilihat pada Tabel 5 . Terdapat korelasi positif yang kuat antara rata-rata total kapang dengan biji rusak, serta korelasi yang sedang antara rata-rata total kapang dengan suhu penyimpanan, kadar air kacang tanah, frekuensi pembersihan langit-langit dan cara penempatan wadah simpan. Suhu penyimpanan yang terukur berada pada kisaran suhu yang mendukung pertumbuhan kapang (OBrian dkk., 2007; Singh dan Chauhan, 2013; Pratiwi dkk., 2015), sementara kadar air kacang tanah diketahui dapat mempengaruhi perkembangan kapang (Rahmianna dkk., 2007a). Infestasi debu dan kotoran, seperti yang teramati pada langit-langit dan lantai kios responden, dapat menjadi sumber penyebaran kapang

Tabel 5. Korelasi keberadaan kapang dengan kondisi penyimpanan (nilai r) dan perilaku pengecer

\begin{tabular}{|c|c|c|c|c|c|c|c|c|c|c|c|}
\hline \multirow{2}{*}{ Koloni } & \multirow{2}{*}{ Suhu } & \multirow{2}{*}{$\mathrm{RH}$} & \multirow{2}{*}{$\mathrm{KA}$} & \multicolumn{5}{|c|}{ Perilaku Pengecer* } & \multicolumn{3}{|c|}{ Kondisi fisik biji** } \\
\hline & & & & $\mathrm{A}$ & $\mathrm{B}$ & $\mathrm{C}$ & $\mathrm{D}$ & $E$ & $\mathrm{BR}$ & $\mathrm{BK}$ & $\mathrm{BB}$ \\
\hline Total kapang & 0,41 & 0,27 & 0,42 & 0,44 & $-0,14$ & 0,44 & NA & NA & 0,74 & $-0,40$ & 0,10 \\
\hline A. flavus & 0,13 & 0,26 & 0,06 & $-0,24$ & $-0,08$ & $-0,24$ & NA & NA & $-0,01$ & $-0,50$ & $-0,06$ \\
\hline
\end{tabular}

* A (frekuensi pembersihan langit-langit), B (frekuensi pembersihan lantai), C (penempatan wadah simpan), D (pencampuran kacang tanah), E (pemilahan biji cacat); NA (data tidak tersedia); **BR (biji rusak), BK (biji keriput), BB (biji belah) 
(Singh dan Chauhan, 2013), sehingga penempatan wadah simpan secara langsung di atas lantai dapat meningkatkan risiko infeksi kapang.

Data pada Tabel 5 menunjukkan bahwa keberadaan $A$. flavus di tingkat pengecer berkorelasi positif dalam tingkat hubungan yang lemah dengan $\mathrm{RH}$ dan cenderung tidak dipengaruhi oleh cara dan kondisi penyimpanan lainnya. Beberapa kondisi penyimpanan, seperti jenis pengemas, tempat penyimpanan dan lama penyimpanan diketahui tidak mempengaruhi tingkat cemaran aflatoksin sebagai racun yang dihasilkan oleh kapang $A$. flavus (Bumbangi dkk., 2016).

Kapang $A$. flavus yang terdeteksi pada sampel kacang tanah dari responden diduga berasal dari tahap transportasi serta penyimpanan di mata rantai distribusi sebelumnya. Komoditas kacang tanah yang dijual oleh pengecer di Jakarta, baik kacang tanah lokal maupun impor, telah melalui beberapa mata rantai distribusi sehingga terdapat peluang komoditas tersebut sudah terinfeksi $A$. flavus. Penelitian yang dilakukan oleh Dharmaputra dkk. (2007b) pada kacang tanah impor menunjukkan adanya infeksi $A$. flavus dan cemaran aflatoksin B1 (AFB1) lebih tinggi dari 15 ppb pada kacang tanah yang diambil dari pelabuhan.

\section{KESIMPULAN}

Perilaku responden baru memenuhi 47-80\% kondisi penyimpanan yang direkomendasikan oleh CAC. Sebagian besar responden belum terbiasa dengan rutinitas pembersihan langit-langit kios, pemberian lapisan di antara wadah simpan dan lantai serta pemilahan biji cacat. Suhu area penyimpanan kacang tanah di tingkat pengecer berkisar antara 29,6 sampai $31,2{ }^{\circ} \mathrm{C}$ yang tidak sesuai dengan rekomendasi CAC serta berada pada kisaran suhu yang mendukung perkembangan kapang. Hal sebaliknya terjadi pada $\mathrm{RH}$ area penyimpanan $(53,6-73,1 \%)$ maupun kadar air kacang tanah $(6,23-7,86 \%)$ yang masih terkendali pada kisaran yang disarankan oleh CAC dan berada di bawah nilai optimum bagi perkembangan $A$. flavus serta produksi aflatoksin. Terdapat korelasi positif antara total kapang dengan keberadaan biji rusak $(r=0,74)$, suhu $(r$ $=0,41)$ dan kadar air $(r=0,42)$ serta perilaku pengecer dalam pembersihan langit-langit kios yang tidak rutin ( $r$ $=0,44$ ) dan kebiasaan menempatkan wadah simpan di atas lantai kios $(r=0,44)$. Frekuensi pembersihan kios yang rendah, cara penempatan wadah simpan secara langsung di atas lantai dan keberadaan biji cacat berpotensi terhadap pertumbuhan kapang $A$. flavus selama dalam penanganannya di tingkat pengecer, apabila didukung oleh kondisi penyimpanan yang tidak sesuai. Jumlah koloni kapang $A$. flavus pada kacang tanah hingga 4,0 log cfu/g ditemukan dalam penelitian ini. Keberadaan kapang $A$. flavus pada sampel cenderung tidak dipengaruhi oleh cara dan kondisi penyimpanan di tingkat pengecer.

\section{DAFTAR PUSTAKA}

Amiri, M.J., Karami, M., \& Sadeghi, E. (2013). Determination of AFB1 in peanut, almond, walnut, and hazelnut in Kermanshah Markets, Iran. International Journal of Agriculture and Crop Sciences, 6(17), 1199-1202.

Badan Meteorologi, Klimatologi, dan Geofisika (2016). Prakiraan Cuaca DKI Jakarta. http://www.bmkg.go.id/cuaca/prakiraan-cuacaindonesia.bmkg?Prov=07\&NamaProv=

DKI\%20Jakarta. [23 Juli-14 Agustus 2016].

Bumbangi, N.F., Muma, J.B., Choongo, K., Mukanga, M., Velu, M.R., Hatloy, A., \& Mapatano, M.A. (2016). Occurrence and factors associated with aflatoxin contamination of raw peanuts from Lusaka district's markets, Zambia. Food Control, 68, 291-296. Doi: 10.1016/j.foodcont.04.004.

Codex Alimentarius Commission (2004). Prevention and Reduction of Aflatoxin Contamination in Peanuts (CAC/RCP 55-2004). Dalam: Codex Alimentarius Commission (ed.). Prevention and Reduction of Food and Feed Contamination, $1^{\text {st }}$ edn, hal 33-43. Secretariat of the Codex Alimentarius Commission, Roma.

Dewan Standarisasi Nasional (1992). Standar Nasional Indonesia SNI 01-3182-1992 tentang Penentuan Kadar Air Biji-bijian, Gaplek dan Bahan Lain Sejenis. Dewan Standarisasi Nasional, Jakarta.

Dewan Standarisasi Nasional (1995). Standar Nasional Indonesia SNI 01-3921-1995 tentang Kacang Tanah. Dewan Standarisasi Nasional, Jakarta.

Dharmaputra, O.S., Retnowati, I., \& Ambarwati, S. (2007a). Aspergillus flavus infection and aflatoxin contamination in peanuts at various stage of the delivery chain in Wonogiri Regency, Central Java, Indonesia. Dalam: Dharmaputra, O.S. (ed.). Fungi, Mycotoxins and Their Control in Indonesian Food and Feedstuff, hal 41-44. SEAMEO BIOTROP. Bogor.

Dharmaputra, O.S., Retnowati, I., Ambarwati, S., \& Maysra, E. (2007b). Aspergillus flavus infection and aflatoxin contamination in imported peanuts at various stage of the delivery chain in West Java, Indonesia. Dalam: Dharmaputra, O.S. (ed.). Fungi, Mycotoxins and Their Control in Indonesian Food and Feedstuff, hal 36-40. SEAMEO BIOTROP. Bogor.

Dharmaputra, O.S., Retnowati, I., \& Ambarwati, S. (2010). Aspergillus flavus infection and aflatoxin contamination in peanuts stored at wholesale and retail levels in Bandung, Bogor and Jakarta (West Java, Indonesia). Dalam: Dharmaputra, O.S. (ed.). Fungi, Mycotoxins and Their Control in Indonesian Food and Feedstuff, hal 127-130. SEAMEO BIOTROP. Bogor.

Dharmaputra, O.S., Ambarwati, S., Retnowati, I., \& Windyarani, A. (2013). Kualitas fisik, populasi Aspergillus flavus, dan kandungan aflatoksin B1 pada biji kacang tanah mentah. Jurnal Fitopatologi Indonesia, 9(4), 99106. Doi: 10.14692/jfi.9.4.99.

Ding, N., Xing, F., Liu, X., Selvaraj, J.N., Wang, L., Zhao, Y., Wang, Y., Guo, W., Dai, X., \& Liu, Y. (2015). Variation in fungal microbiome (mycobiome) and aflatoxin in stored in-shell peanuts at four different areas of China. Frontiers in Microbiology, 6, 1-10. Doi: 10.3389/fmicb.2015.01055.

Ginting, E., Yulifianti, R., \& Utomo, J.S. (2015). Standar mutu kacang tanah. Dalam: Kasno A, Rahmianna A.A., Mejaya I.M.J., Harnowo D., Purnomo S. (edited). Kacang Tanah, 
Inovasi Teknologi dan Pengembangan Produk hal 394-406. Balitkabi. Malang.

Ginting, E., \& Rahmianna A.A. (2015). Infection of Aspergillus flavus and physical quality of peanuts collected from farmers, local markets, and processors. Procedia Food Science, 3, 280-288. Doi:10.1016/j.profoo.01.031.

Guchi E. (2015). Stakeholders' perception about aflatoxin contamination in groundnut (Arachis hypogaea L.) along the value chain actors in eastern Ethiopia. International Journal of Food Contamination, 2(10), 1-7. Doi: 10.1186/s40550-015-0014-2.

International Seed Testing Association (2016). International Rules for Seed Testing 2016, Chapter 2: Sampling. International Seed Testing Association, Bassersdorf.

Khodavaisy, S., Maleki, A., Hossainzade, B., Rezai, S., Ahmadi, F., Validi, A., Rashidi, A., \& Ghahramani, E. (2012). Occurrence of fungal contamination in pistachio and peanut samples from retail shops in Sanandaj province, Iran. African Journal of Microbiology Research, 6(39), 67816784. Doi: 10.5897/AJMR12.722.

Khosravi, A.L., Shokri, H., \& Ziglari, T. (2007). Evaluation of fungal flora in some important nut products (pistachio, peanut, hazelnut and almond) in Tehran, Iran. Pakistan Journal of Nutrition, 6(5), 460-462.

Loreen, D., \& Moses, M. (2015). Assessment of aflatoxin awareness by players in groundnut value chain: The case of Dora in Mutare, Zimbabwe. International Journal of Innovative Research and Development, 4(10), 90-100.

Mohammadi, A.H., Banihashemi, Z., \& Haghdel, M. (2009). Identification and prevalence of Aspergillus species in soils of Fars and Kerman Provinces of Iran and evaluation of their aflatoxin production. Rostaniha, 10(1), 8-30.

Mohammed, A., \& Chala, A. (2014). Incidence of Aspergillus contamination of groundnut (Arachis hypogaea L.) in Eastern Ethiopia. African Journal of Microbiology Research, 8(8), 759-765. Doi: 10.5897/AJMR12.2078.

Mutegi, C.K., Wagacha, J.M., Kimani, J., Otieno, G., Wanyama, R., Hell, K., \& Christie, M.E. (2013a). Incidence of aflatoxin in peanuts (Arachis hypogaea Linnaeus) from markets in Western, Nyanza and Nairobi Provinces of Kenya and related market traits. Journal of Stored Products Research, 52, 118-127. Doi:10.1016/j.jspr.10.002.

Mutegi, C.K., Wagacha, J.M., Christie, M.E., Kimani, J., \& Karanja, L. (2013b). Effect of storage conditions on quality and aflatoxin contamination of peanuts (Arachis hypogaea L.). International Journal of AgriScience, 3(10), 746-758.

Nakai, V.K., de Oliveira Rocha, L., Gonçalez, E., Fonseca, H., Ortega, E.M.M., \& Corrêa, B. (2008). Distribution of fungi and aflatoxin in a stored peanut variety. Food Chemistry, 106, 285-290. Doi:10.1016/j.foodchem.05.087.

N'dede, C.B., Jolly, C.M., Vodouhe, S.D., \& Jolly, P.E. (2012). Economic risks of aflatoxin contamination in marketing of peanut in Benin. Economics Research International, 1-12. Doi: $10.1155 / 2012 / 230638$.

Nyirahakizimana, H., Mwamburi, L., Wakhisi, J., Mutegi, C.K., Christie, M.E., \& Wagacha, J.M. (2013). Occurrence of Aspergillus species and aflatoxin contamination in raw and roasted peanuts from formal and informal markets in Eldoret and Kericho Towns, Kenya. Advances in Microbiology, 3, 333-342.

OBrian, G.R., Georgianna, D.R., Wilkinson, J.R., Yu, J., Abbas, H.K., Bhatnagar, D., Nierman, W., \& Payne, G.A. (2007). The effect of elevated temperature on gene transcription and aflatoxin biosynthesis. Mycologia, 99(2), 232-239.

Odoemelam, S.A., \& Osu C.I. (2009). Aflatoxin B1 contamination of some edible grains marketed in Nigeria. E-Journal of Chemistry, 6(2), 308-314.

Perrone, G., Susca, A., Cozzi, G., Ehrlich, K., Varga, J., Frisvad, J.C., Meijer, M., Noonim, P., Mahakarnchanakul, W., \& Samson, R.A. (2007). Biodiversity of Aspergillus species in some important agricultural products. Studies in Mycology, 59, 53-66. Doi: 10.3114/sim.2007.59.07.

Pitt, J.I., Hocking, A.D., \& Glenn, D.R. (1983). An improved medium for the detection of Aspergillus flavus and $A$. parasiticus. Dalam: Hocking, A.D., Pitt, J.I., Samson, R.A., Thrane, U. (ed.). Advances in Food Mycology, hal 346. Springer, New York.

Pratiwi, C., Rahayu, W.P., Lioe, H.N., Herawati, D., Broto, W., \& Ambarwati, S. (2015). The effect of temperature and relative humidity for Aspergillus flavus BIO 2237 growth and aflatoxin production on soybeans. International Food Research Journal, 22(1), 82-87.

Pusat Data dan Sistem Informasi Pertanian (2015). Outlook Komoditas Pertanian Tanaman Pangan Kacang Tanah. Pusat Data dan Sistem Informasi Pertanian, Jakarta.

Rahmianna, A.A., Ginting, E., \& Yusnawan, E. (2007a). Cemaran aflatoksin B1 pada kacang tanah yang diperdagangkan di sentra produksi Banjarnegara. Penelitian Pertanian Tanaman Pangan, 26(2), 137-144.

Rahmianna, A.A., Taufiq, A., \& Yusnawan, E. (2007b). Effect of harvest timing and postharvest storage conditions on aflatoxin contamination in groundnuts harvested from the Wonogiri regency in Indonesia. Journal of SAT Agricultural Research, 5(1), 1-3.

Rahmianna, A.A., \& Yusnawan, E. (2015). Monitoring of aflatoxin contamination at market food chain in East Java. Journal of Experimental Biology and Agricultural Sciences, 3(4), 346-352.

Riba, A., Matmoura, A., Mokrane, S., Mathieu, F., \& Sabaou, N. (2013). Investigations on aflatoxigenic fungi and aflatoxins contamination in some nuts sampled in Algeria. African Journal of Microbiology Research, 742 ), 49744980. Doi: 10.5897/AJMR2013.5867.

Rostami, R., Naddafi, K., Aghamohamadi, A., Najafisaleh, H., \& Fazlzadehdavil, M. (2009). Survey of peanut contamination and its relationship with ambient conditions in the bazar of Zanjan. Iranian Journal of Environmental Health Science and Engineering, 6(4), 295-300.

Santos, F., Medina, P.F., Lourenção, A.L., Parisi J.J.D., \& de Godoy, I.J. (2016). Damage caused by fungi and insects to stored peanut seeds before processing. Plant Protection, 75(2), 184-192.

Shehu, K., \& Bello, M.T. (2011). Effect of environmental factors on the growth of Aspergillus species associated with stored millet grains in Sokoto. Nigerian Journal of Basic and Applied Science, 19(2), 218-223.

Singh, P., \& Chauhan, M. (2013). Influence of environmental factors on the growth of building deteriorating fungi: Aspergillus flavus and Penicillium chrysogenum. International Journal of Pharmaceutical Sciences and Research, 4(1), 425-429.

Swastika, D.K.S. (2015). Ekonomi kacang tanah di Indonesia. Dalam: Kasno, A., Rahmianna, A.A., Mejaya, I.M.J., Harnowo, D., Purnomo, S. (ed.). Kacang Tanah, Inovasi Teknologi dan Pengembangan Produk, hal 1-17. Monograf Balitkabi No. 13. Malang.

Tournas, V., Stack, M.E., Mislivec, P.B., Koch, H.A., \& Bandler, R. (2001). Chapter 18 Yeasts, Molds and Mycotoxins. Bacteriological Analytical Manual Online, $8^{\text {th }}$ Edition. 
http://www.fda.gov/Food/FoodScienceResearch/Laboratory Methods/ucm071435.htm. [7 Oktober 2016].

Yassin, M.F., \& Almouqatea, S. (2010). Assessment of airborne bacteria and fungi in an indoor and outdoor environment. International Journal of Environmental Science and Technology, 73), 535-544.

Zhang, C., Selvaraj, J.N., Yang, Q., \& Liu, Y. (2017). A survey of aflatoxin-producing Aspergillus sp. from peanut field soils in four agroecological zones of China. Toxins, 9(40), 1-14. Doi: $10.3390 /$ toxins 9010040 . 